\title{
Phylogenetic diversity and vertical distribution of a halobacterial community in the atmosphere of an Asian dust (KOSA) source region, Dunhuang City
}

\author{
Teruya Maki • Shinzi Susuki • Fumihisa Kobayashi • \\ Makiko Kakikawa • Maromu Yamada • \\ Tomomi Higashi • Bin Chen • Guangyu Shi • \\ Chunsang Hong • Yutaka Tobo • Hiroshi Hasegawa • \\ Kazumasa Ueda • Yasunobu Iwasaka
}

Received: 25 July 2008 /Accepted: 3 September 2008 /Published online: 30 September 2008

(C) The Author(s) 2008. This article is published with open access at Springerlink.com

\begin{abstract}
The microbial communities transported by Asian desert dust (KOSA) events have attracted much attention as bioaerosols because the transported microorganisms are thought to influence the downwind ecosystems in Korea and Japan. We have analyzed bioaerosol samples collected at 10 and $800 \mathrm{~m}$ above the ground within the KOSA source area, Dunhuang City, China. The samples were studied by epifluorescent microscopy, revealing the presence of bacterial cells attached to mineral particles. The microorganisms in the bioaerosol samples were able to grow in media containing up to $20 \% \mathrm{NaCl}$, suggesting that bacteria tolerant to high salinities remain viable in the atmosphere. Phylogenetic analysis using 16S rDNA sequences revealed that halobacterial communities in the bioaerosol samples collected at both 10 and $800 \mathrm{~m}$ above the ground comprised a few bacterial species related to Bacillus pumilus and Staphylococcus spp. The active mixing processes of the boundary layer presumably transports viable halotolerant
\end{abstract}

T. Maki $(\bowtie) \cdot$ S. Susuki $\cdot$ F. Kobayashi $\cdot$ H. Hasegawa $\cdot$ K. Ueda College of Science and Engineering, Kanazawa University,

Kakuma, Kanazawa, Ishikawa 920-1192, Japan

e-mail: makiteru@t.kanazawa-u.ac.jp

\section{Kakikawa}

Institute of Nature and Environmental Technology,

Kanazawa University,

Kakuma, Kanazawa, Ishikawa 920-1192, Japan

M. Yamada

Faculty of Environmental and Symbiotic Science,

Prefectural University of Kumamoto,

3-1-100 Tsukide,

Kumamoto 862-8502, Japan bacteria into the free atmosphere, where the long-range atmospheric transport of desert dust is frequently observed.

Keywords Asian dust $\cdot$ Bioaerosol $\cdot$ Halophilic bacteria . Halotolerant bacteria $\cdot \mathrm{KOSA} \cdot \mathrm{NaCl}$

\section{Introduction}

Asian desert dust (KOSA) that originates in desert regions of northern China, such as the Gobi and the Takla Makan Deserts, can carry desert aerosols (Duce et al. 1980; Iwasaka et al. 1983) and possibly impact ecosystem and human health in the downwind environments of Korea and Japan (Iwasaka et al. 1988). Both the mineral dust as well as the microbial communities that are transported by dust storms have been the focus of considerable attention in recent years (Prospero et al. 2005). Bioaerosol particles,

\section{T. Higashi}

Hygiene, Kanazawa University School of Medicine,

13-1 Takara-machi,

Kanazawa 920-8640, Japan

B. Chen $\cdot$ G. Shi

Guangyu Shi, Institute of Atmospheric Physics,

Chinese Academy of Sciences,

Beijing 100029, China

C. Hong $\cdot$ Y. Tobo $\cdot$ Y. Iwasaka

Frontier Science Organization, Kanazawa University,

Kakuma, Kanazawa, Ishikawa 920-1192, Japan 
such as viruses, bacteria, fungi, and pollen, as well as plant and animal debris (Jones and Harrison 2004) are reported to negatively influence plant and animal health and cause diseases, such as asthma (due to allergens) or other illnesses (Griffin 2007; Griffin and Kellogg 2004; Kellogg and Griffin 2006). Bioaerosol research has developed very rapidly during the last two decades (Grinshpun and Clark 2005; Mancinelli and Shulls 1987), but accumulated data of microbial communities in the atmosphere are primarily limited to the Caribbean area and the Americas, which are most affected by dust storms originating in the Sahara and Sahel regions of North Africa (Griffin et al. 2006; Kellogg et al. 2004). Only a few studies have focused on the microorganisms traveling from the KOSA source areas towards Japan and Korea (Wu et al. 2004; Yeo and Kim 2002), but the physiological characteristics and microbial species compositions of the atmospheric bioaerosols in the KOSA source area have not yet been clarified.

The ability of a microorganism to survive in the atmosphere is a function of its ability to withstand desiccation, extreme temperature, oxygen limitation, and exposure to ultraviolet (UV) radiation (Alan and Harrison 2004; Imshenetsky et al. 1978). Halobacteria, such as halotolerant bacteria and halophilic bacteria, are known to tolerate conditions of high salinity and are resistant to stresses, such as high $\mathrm{pH}$, extreme temperature, or desiccation (Rothschild and Mancinelli 2001; Russell 1989). As such, the halobacterial community represents a good model system for studying atmospheric travel of bioaerosols across hundreds to thousands of kilometers at low to extreme altitudes (Echigo et al. 2005; Okamoto et al. 2004).

Previous studies on long-range bacterial transports by dust storms have targeted only culturable bacteria (Griffin et al. 2003, 2006; Kellogg et al. 2004). However, it is recognized that $90-99 \%$ of bacteria in natural environments cannot be cultivated by traditional methods and that many are viable but unculturable (Olsen and Bakken 1987). A culture-independent method, consisting of a denaturing gradient gel electrophoresis (DGGE) analysis of bacterial 16S rRNA genes PCR-amplified from DNA directly extracted from environmental samples (Muyzer et al. 1993), demonstrated that the composition of bacterial species were influenced by the dynamics of environmental factors in terrestrial (Lorenz et al. 2006) or aquatic environments (Suehiro et al. 2006). However, little information is available on desert dust transport of unculturable bacteria.

In this study, bioaerosol samples were collected in August 2007 at heights of 10 and $800 \mathrm{~m}$ above the ground in Dunhuang City on the eastern border of the Takla Makan Desert (Fig. 1). The viabilities of halobacterial communities in the bioaerosol samples were evaluated with the $\mathrm{NaCl}$ amendment assay using culture media supplemented with different $\mathrm{NaCl}$ concentrations. The bacterial species identified in the microbial cultures with $\mathrm{NaCl}$ amendment and in the genomic DNA of environmental bioaerosol samples were analyzed by PCR-DGGE analysis of $16 \mathrm{~S}$ rDNA.

\section{Experiment}

\section{Sampling}

Bioaerosol sampling was performed on the campus of the Dunhuang City Meteorological Department $\left(40.0^{\circ} \mathrm{N}, 94.5^{\circ} \mathrm{E}\right)$ on August 16, in 2007 (Fig. 1). Dunhuang City is located on the eastern border of the Takla Makan Desert, which is the source area of KOSA traveling towards Japan and Korea. The bioaerosol sample was collected $800 \mathrm{~m}$ above the ground using a tethered balloon (Yamada et al. 2005), while that collected $10 \mathrm{~m}$ above ground was collected from the roof of a building. T collection procedure at each altitude consisted of an air pump with a $0.45-\mu \mathrm{m}$ membrane filter that sampled $0.7 \mathrm{~m}^{3}$ of air in the course of $1 \mathrm{~h}$ during the day. The $1-\mathrm{h}$ sampling time was a maximum length of time thate the air pump could function at $800 \mathrm{~m}$ before the battery ran down. Prior to sampling, the filters were autoclaved with a filter holder (In-Line Filter Holder, $47 \mathrm{~mm}$; Millipore, Tokyo, Japan). Environmental factors, such as temperatures and particle numbers in the atmosphere, were determined using a thermometer (EX-501: EMPEX Instruments, Tokyo, Japan) and a particle counter (KR-12A; RION, Tokyo, Japan), respectively (Fig. 2). The mean temperatures of the atmosphere at $800 \mathrm{~m}$ and below $20 \mathrm{~m}$ were 14.7 and $22.5^{\circ} \mathrm{C}$, respectively, and the mean relative humidity (RH) values were 92.1 and $56.3 \%$, respectively. Within $1 \mathrm{~h}$ of sampling, the bacterial particles on the filter were washed off by the shaking with $10 \mathrm{ml}$ of sterilized water containing $0.9 \%(\mathrm{w} / \mathrm{v})$ of $\mathrm{NaCl}$. The wash solution was used for the observation of KOSA particles under the epifluorescent microscope and for the determination of the bacterial species composition by the PCRDGGE analysis. The eluted wash solution was also utilized as the cultivation spike in media containing different $\mathrm{NaCl}$ concentrations to investigate the viabilities of halobacteria.

\section{Epifluorescence microscopy}

A 1-ml aliquot of the filter wash solution was fixed with a glutaraldehyde solution at a final concentration of $1 \%$. The samples were stained with DAPI (4',6-diamino-2-phenylindole) at a final concentration of $0.5 \mu \mathrm{g} / \mathrm{mL}$ for $15 \mathrm{~min}$ and filtered through $0.2-\mu \mathrm{m}$ pore-sized membrane filters stained with Sudan Black (Porter and Feig 1980; Russell et al. 1974). The mineral particles on the filters and the bacterial cells attached to the mineral particles were observed using 
Fig. 1 Sampling site (Dunhuang City) and KOSA (Asian desert dust) source regions (Gobi and Takla Makan Deserts)

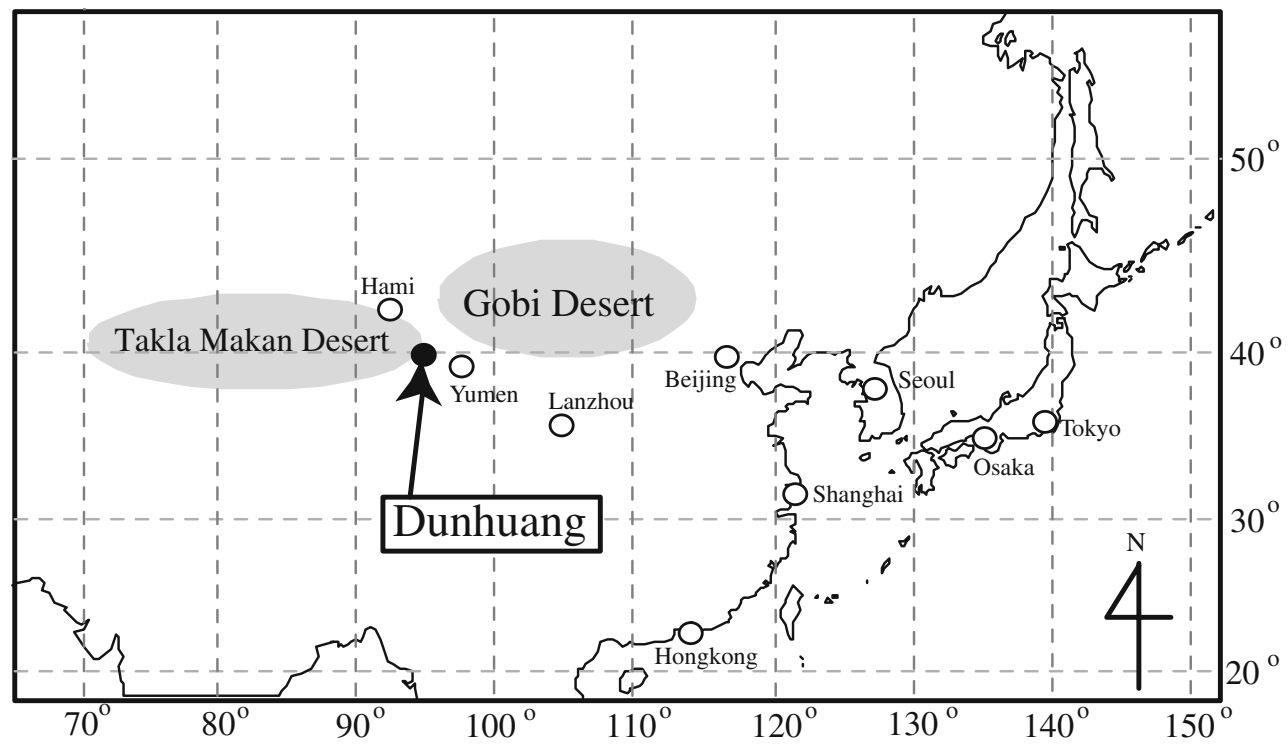

an epifluorescence microscope (Olympus, Tokyo, Japan) under UV excitation (Fig. 3).

Physiological experiments

To investigate the viabilities of halotolerant bacteria, we inoculated $1 \mathrm{ml}$ of the wash solution into $19 \mathrm{ml}$ of Tryptic Soy Broth (TS) media supplemented with $\mathrm{NaCl}$ to final concentrations of $0,3,10$, and $20 \%(\mathrm{w} / \mathrm{v})$. The TS medium comprised $17 \mathrm{~g}$ trypticasepeptone, $5 \mathrm{~g}$ phytonepeptone, $2.5 \mathrm{~g} \mathrm{~K}_{2} \mathrm{PO}_{4}$, and $2.5 \mathrm{~g}$ glucose in 11 of pure water. Tryptic Soy Broth medium has often been used for detecting and isolating bacteria from bioaerosol samples (Fabian et al. 2005; Kalogerakis et al. 2005). After the microorganisms in the bioaerosol samples were cultivated in the media at $20^{\circ} \mathrm{C}$ in the dark, microbial growth was estimated at $550 \mathrm{~nm}$ absorbance every 2 days (Fig. 4). After 14 days of incubation, $5 \mathrm{ml}$ of the microbial cultures was used for

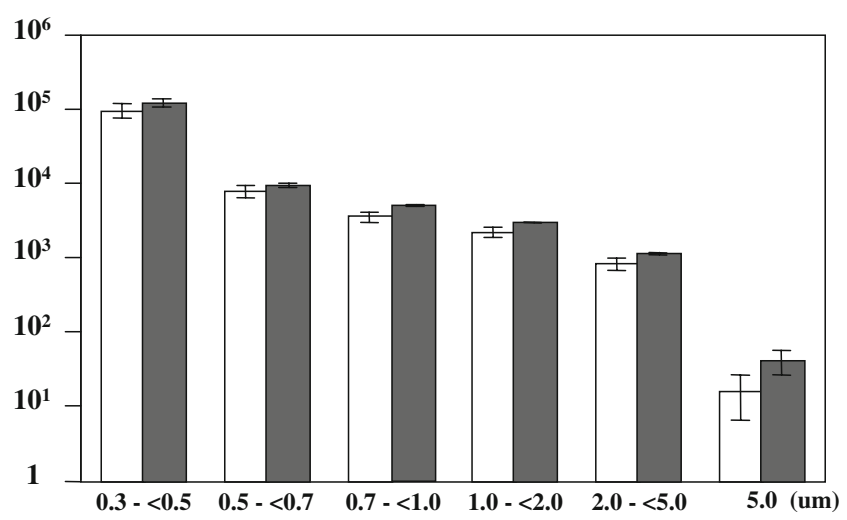

Fig. 2 Particle concentrations of each diameter size category in the atmosphere at $800 \mathrm{~m}$ (white bars) and below $20 \mathrm{~m}$ (grey bars) above ground determining species diversity by PCR-DGGE $16 \mathrm{~S}$ rDNA analysis.

PCR-DGGE analysis of bacterial 16S rDNA

One milliliter of the filter wash solution of bioaerosol samples collected at 10 and $800 \mathrm{~m}$ and $5 \mathrm{ml}$ of the microbial cultures with $\mathrm{NaCl}$ amendment were used for the extraction of genomic DNAs using sodium dodecyl sulfate (SDS), proteinase $\mathrm{K}$, and lysozyme as described previously (Maki et al. 2004). The genomic DNAs were purified by phenol-chloroform extraction, chloroform extraction, and ethanol precipitation. A 16S rDNA region (approx. $550 \mathrm{bp}$ ) of the extracted genomic DNAs were amplified by PCRusing oligonucleotide primers for PCR-DGGE analysis, which were F341-GC (5'- CGC CCG CCG CGC CCC GCG CCC GTC CCG CCG CCC CCG CCC GCC TAC GGG AGG CAG CAG-3') and R907 (5'-CCG TCA ATT CCT TT[A/G] AGT TT-3') (Muyzer et al. 1993). For each PCR reaction, $10 \mathrm{ng}$ of the extracted DNAs was added to a PCR mastermix $(20 \mu \mathrm{l})$, which contained $2 \mu \mathrm{mol} / \mathrm{l}$ dNTPs (TaKaRa, Ohtsu, Japan), $2 \mathrm{nmol} / \mathrm{l}$ each of the primers, and $1 \mathrm{U}$ of Taq DNA polymerase (TaKaRa). Thermal cycling was performed using a Program Temp Control System PC700 (ASTEC, Fukuoka, Japan) with a thermal cycling program, as follows: a 5 -min denaturing step at $94^{\circ} \mathrm{C}$, followed by 34 cycles of $1 \mathrm{~min}$ at $94^{\circ} \mathrm{C}, 1 \mathrm{~min}$ at $55^{\circ} \mathrm{C}$, and $2 \mathrm{~min}$ at $72^{\circ} \mathrm{C}$ and a final 10 -min extension step at $72^{\circ} \mathrm{C}$. Amplification was verified by agarose gel electrophoresis $(1.5 \%, \mathrm{w} / \mathrm{v}$, agarose gel).

The DGGE analysis was performed on a $6 \%$ acrylamide gels containing a linear gradient of denaturant from 40 to $60 \%$ [ $100 \%$ denaturant contained $7 \mathrm{~mol} / 1$ of urea and $40 \%$ (v/v) formamide]. Electrophoresis was carried out at $60^{\circ} \mathrm{C}$ 
Fig. 3 Epifluorescence micrograph of KOSA particles in the bioaerosol sample collected at $800 \mathrm{~m}$
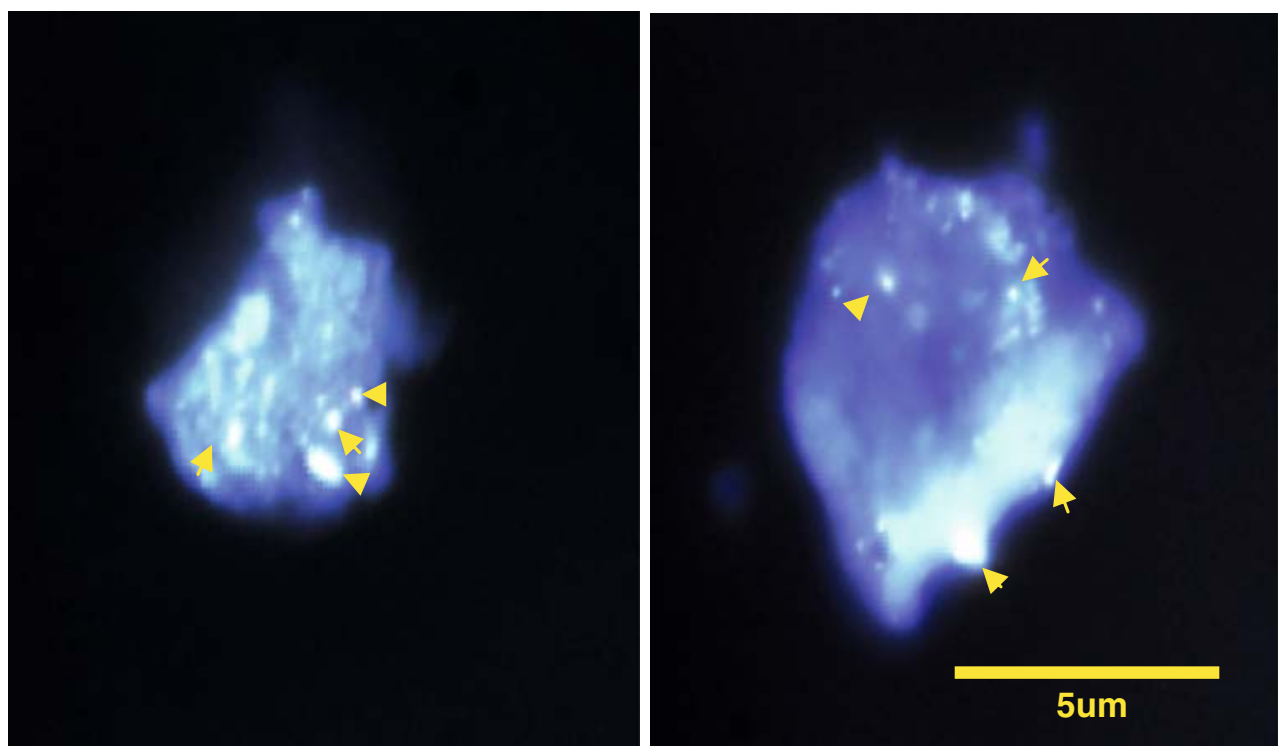

and $90 \mathrm{~V}$ for $16 \mathrm{~h}$ in a $1 \times$ TAE buffer with an electrophoresis system (AE-6290; ATTA, Tokyo, Japan). After electrophoresis, the gels were stained with SYBR Gold and scanned in a Printgraph (AE-6933FXCF; ATTA) (Fig. 5). Several bands on the gels were excised for sequencing. The excised gel pieces were transferred to PCR tubes, and the PCR amplicons (approx. $550 \mathrm{bp}$ ) were purified by phenol-chloroform extraction and chloroform extraction followed by ethanol precipitation. The nucleotide sequences were determined using a Dye Deoxy Terminator Cycle Sequencing kit (ABI, Foster City, USA) and a DNA autosequencing system (model 373A; ABI) according to the manufacturer's recommended protocol. Primer F-341 without a GC clamp was used as the sequencing primer.

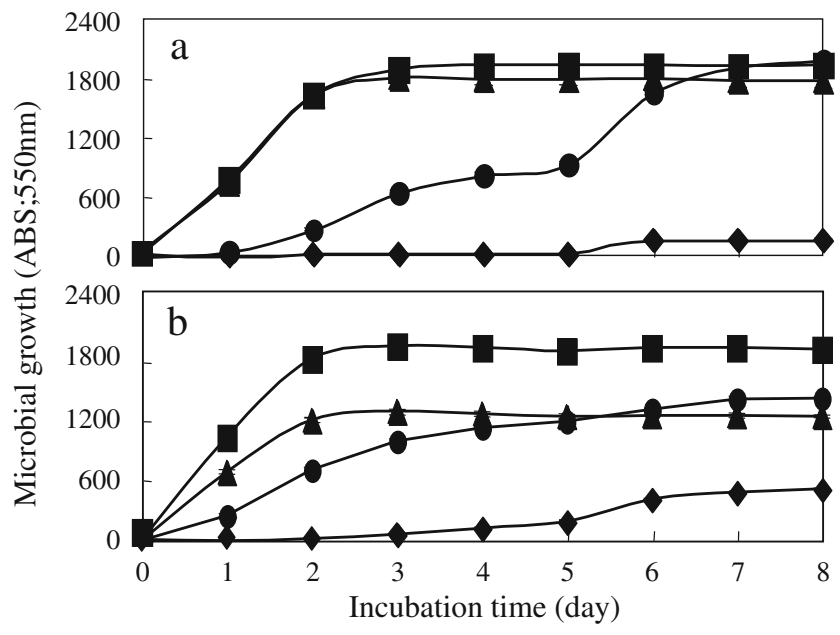

Fig. 4 Microbial growth of the bioaerosol samples collected at heights of $800 \mathrm{~m}$ (a) and $10 \mathrm{~m}$ (b) in the Tryptic Soy Broth (TS) media supplemented with $\mathrm{NaCl}$ at concentrations of $0 \%$ (square), $3 \%$ (triangle), 10\% (circle) and 20\% (diamond). All experiments were performed in triplicate. $A B S$ Absorbance at $550 \mathrm{~nm}$
The determined sequences were compared with a DDBJ (DNA Data Bank of Japan) database using the BLAST and FASTA SEARCH programs (Table 1). A phylogenetic tree including all sequences was constructed according to the neighbor-joining algorithmic method using TreeViewPPC (Saitou and Nei 1987) (Fig. 6).

Nucleotide sequence accession numbers

The DDBJ accession numbers for the partial 16S rRNA gene sequences are AB455151 to AB455158.

\section{Results}

Environmental factors and epifluorescence microscopy

The atmosphere at $800 \mathrm{~m}$ above the ground in Dunhuang City included fewer aerosol particles of every diameter category than that below $20 \mathrm{~m}$ above the ground. The size distributions of the particle numbers were similar between the atmosphere at $800 \mathrm{~m}$ and that below $20 \mathrm{~m}$ above the ground (Fig. 2), indicating that atmospheric constituents were well mixed. At the heights of $800 \mathrm{~m}$ and below $20 \mathrm{~m}$, there were high concentrations of particles between 0.3 and $0.5 \mu \mathrm{m}$ in diameter, with more than 91,000 particles/1, which represents about $90 \%$ of the total number of particles greater than $0.3 \mu \mathrm{m}$. In addition, particles between 0.5 and $2.0 \mu \mathrm{m}$ in diameter were present at concentrations one order of magnitude lower than those between 0.3 and $0.5 \mu \mathrm{m}$, ranging from 2100 to 9200 particles/1. Relatively large particles greater than $2.0 \mu \mathrm{m}$ were also detected at heights of $800 \mathrm{~m}$ and below $20 \mathrm{~m}$, and the total concentrations ranged from 800 to 1150 particles/1. 


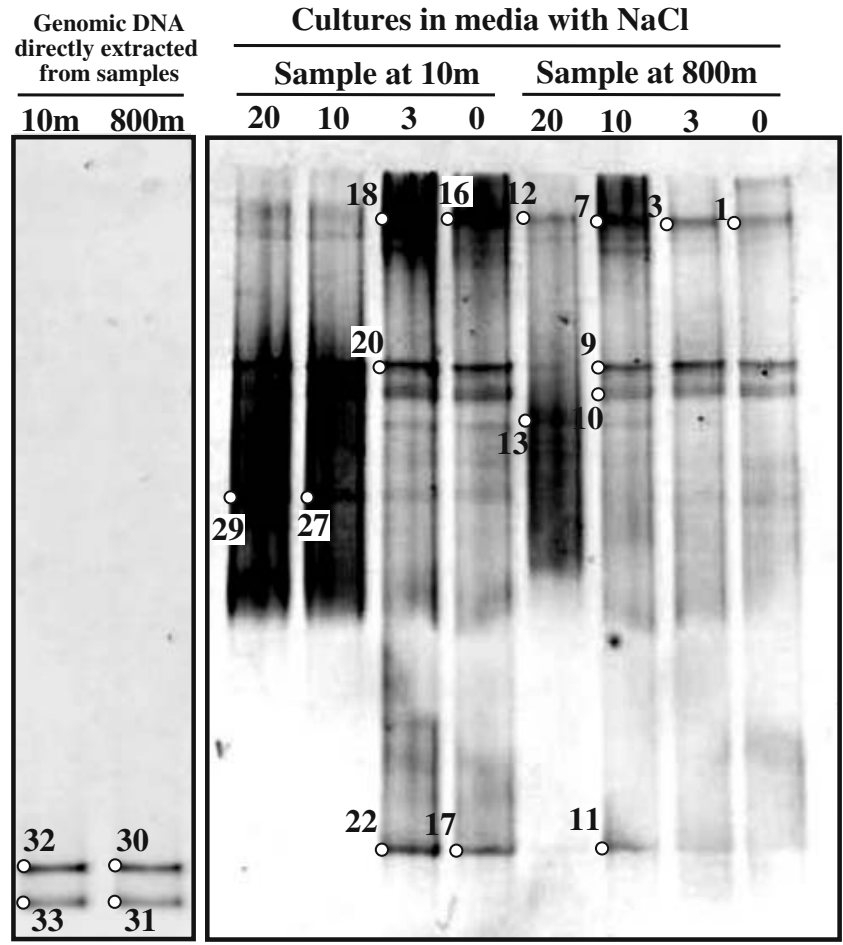

Fig. 5 The denaturing gradient gel electrophoresis (DGGE) profile (band patterns) of amplified 16S rDNA from genomic DNA directly extracted from bioaerosol samples collected at 10 and $800 \mathrm{~m}$ above the ground and from the bacterial cultures of bioaerosol samples collected at 10 and $800 \mathrm{~m}$ that had been cultivated in TS media containing $0,3,10$, and $20 \% \mathrm{NaCl}$, respectively. A $40 \%$ (upper) to $60 \%$ (lower) denaturing gradient was used. Numbers indicate the DGGE bands subsequently excised and sequenced (see Table 1)

Epifluorescence microscopy after DAPI staining revealed that the mineral particles collected at a height of $800 \mathrm{~m}$ were relatively large particles with white-blue selffluorescence and a diameter of more than $5 \mu \mathrm{m}$ (Fig. 3). The bacterial particles stained with DAPI, which were observed as small particles with bright-blue fluorescence, were located on the mineral particles and were coccoid-like, with a diameter of less than $1 \mu \mathrm{m}$. The mineral particles with attached bacteria made up approximately $10 \%$ of the total mineral particles, with the remaining mineral particles possessing few or no bacterial cells.

\section{Physiological culture}

When the bioaerosol samples were cultivated in TS media supplemented with different $\mathrm{NaCl}$ concentrations, microbial growth in media containing 0 and $3 \% \mathrm{NaCl}$ was rapid within 3 days of incubation and with absorbances that fluctuated over 1200 (approx. $5.0 \times 10^{8}$ to approx. $1.0 \times 10^{9}$ cells $/ \mathrm{ml}$ ) during the experimental period (Fig. 4). In the medium containing $10 \% \mathrm{NaCl}$, the microorganisms of both samples $(10 \mathrm{~m}$ and $800 \mathrm{~m})$ gradually increased to an absorbance of more than 1200 absorbance during 7 days of incubation. The cultures in $20 \% \mathrm{NaCl}$ showed only weak microbial growth until the sixth day, maintaining low absorbance values below 600 (approximately $3.0 \times 10^{8}$ cells/ml) during the experimental period.

DGGE analysis of the bacterial communities

The composition of the bioaerosol samples in terms of bacterial species was compared by PCR-DGGE analysis targeting bacterial 16S rRNA genes (Fig. 5). Analysis of the PCR products amplified from the genomic DNA directly extracted from each bioaerosol sample revealed two common DGGE bands (DDd-30, DDd-31, DDd-32, and DDd-33) on the gel. Moreover, the DGGE banding patterns were similar in the bioaerosol samples collected at 10 and $800 \mathrm{~m}$, indicating that similar bacterial species dominated in the samples collected at both altitudes. The bacterial community of the microbial cultures cultivated in media containing $0,3,10$, and $20 \mathrm{NaCl}$, respectively, was also investigated using PCR-DGGE analysis (Fig. 5). In the media containing 0 and $3 \% \mathrm{NaCl}$, the DGGE bands of microbial cultures showed the same banding patterns in the bioaerosol samples collected at 10 and $800 \mathrm{~m}$, suggesting that the bacterial community which grew in low-salinity media had similar species compositions. A few bands in the upper (DAd-1, DAd-3, DAd-7, DAd-12, DAd-16, and DAd-18) and the middle gel segments (DAd-9, DAd-10 and DAd-20) were detected from the microbial cultures at all $\mathrm{NaCl}$ concentrations tested, while other bands in the lower segments (DAd-11, DAd-17, and DAd-22) of the gel appeared only in the microbial cultures at 0,3 , and $10 \%$ $\mathrm{NaCl}$. The remaining bands (DAd-13, DAd-27, and DAd29) were specific to the microbial cultures cultured in 10 and/or $20 \% \mathrm{NaCl}$ and were different from the samples collected at 10 and $800 \mathrm{~m}$. This result indicates that the species composition of the bacterial community in the atmosphere at $800 \mathrm{~m}$, which requires high $\mathrm{NaCl}$ concentrations, are different from those in the atmosphere at $10 \mathrm{~m}$.

We excised and sequenced 19 bands from the DGGE gel (Fig. 5). Eight phylotypes were obtained after comparing the sequences with each other and with the bacterial 16S rDNA databases (Table 1). All sequences belonged to the Gram-positive bacterial group and clustered with the members of the genus Bacillus and the genus Staphylococcus (Fig. 6). Moreover, three phylotypes among all eight phylotypes were obtained from bioaerosol samples collected at both 10 and $800 \mathrm{~m}$, indicating the presence of similar bacterial species in the atmospheres at both altitudes. The sequences of DAd-11, DAd-17, and DAd-22 obtained from the microbial cultures of 0,3 , and $10 \% \mathrm{NaCl}$ and the sequences of DDd-30 and DDd-32 from the DNA directly extracted 
Table 1 Phylogenetic affiliation of sequences contained in the DGGE bands

\begin{tabular}{|c|c|c|c|c|c|c|c|}
\hline DGGE band no. ${ }^{\mathrm{a}}$ & $\begin{array}{l}\text { Sampling } \\
\text { location }(\mathrm{m})^{\mathrm{b}}\end{array}$ & Sample conditon ${ }^{\mathrm{c}}$ & $\begin{array}{l}\text { Length } \\
\text { (bp) }\end{array}$ & Category & $\begin{array}{l}\text { GenBank } \\
\text { accession no. }\end{array}$ & Closest relative & $\begin{array}{l}\text { Similarity } \\
(\%)^{\mathrm{d}}\end{array}$ \\
\hline $\begin{array}{l}\text { DAd-1, }-3,-7,-12 \text {, } \\
\quad-16,-18\end{array}$ & 10 and 800 & $<20 \% \mathrm{NaCl}$ & 481 & $\begin{array}{l}\text { Gram- } \\
\text { positive } \\
\text { group }\end{array}$ & AB455151 & Bacillus pumilus & 99.4 \\
\hline DAd-9 & 800 & $10 \% \mathrm{NaCl}$ & 424 & $\begin{array}{l}\text { Gram- } \\
\text { positive } \\
\text { group }\end{array}$ & AB455152 & B. pumilus & 97.4 \\
\hline DAd-10 & 800 & $10 \% \mathrm{NaCl}$ & 422 & $\begin{array}{l}\text { Gram- } \\
\text { positive } \\
\text { group }\end{array}$ & AB455153 & B. pumilus & 96.7 \\
\hline $\begin{array}{l}\text { DAd-11, }-17,-22 ; \\
\text { DDd-30, -32 }\end{array}$ & 10 and 800 & $\begin{array}{l}<10 \% \mathrm{NaCl} \text { - directly } \\
\text { extracted DNA }\end{array}$ & 473 & $\begin{array}{l}\text { Gram- } \\
\text { positive } \\
\text { group }\end{array}$ & AB455154 & B. pumilus & 99.6 \\
\hline DAd-13 & 800 & $20 \% \mathrm{NaCl}$ & 485 & $\begin{array}{l}\text { Gram- } \\
\text { positive } \\
\text { group }\end{array}$ & AB455155 & $\begin{array}{l}\text { Staphylococcus } \\
\text { epidermidis }\end{array}$ & 99.8 \\
\hline DAd-20 & 10 & $3 \% \mathrm{NaCl}$ & 424 & $\begin{array}{l}\text { Gram- } \\
\text { positive } \\
\text { group }\end{array}$ & AB455156 & B. pumilus & 98.1 \\
\hline DAd-27, -29 & 10 & $20 \% \mathrm{NaCl}$ & 486 & $\begin{array}{l}\text { Gram- } \\
\text { positive } \\
\text { group }\end{array}$ & AB455157 & $\begin{array}{l}\text { Staphylococcus } \\
\text { xylosus }\end{array}$ & 100 \\
\hline DDd-31, -33 & 10 and 800 & $\begin{array}{l}\text { Directly extracted } \\
\text { DNA }\end{array}$ & 487 & $\begin{array}{l}\text { Gram- } \\
\text { positive } \\
\text { group }\end{array}$ & AB455158 & B. pumilus & 99.6 \\
\hline
\end{tabular}

DGGE, Denaturing gradient gel electrophoresis

${ }^{a}$ Numbers of the bands in Fig. 3 refer to the numbering of the DAd or DDd series

${ }^{\mathrm{b}}$ Height above ground (in meters)

${ }^{\mathrm{c}}$ Cultures cultivated with $\mathrm{NaCl}$ at concentrations of $0,3,10$ and 20, and genomic DNA directly extracted from the bioaerosol samples

${ }^{\mathrm{d}}$ Similarity value between each isolate and the closest relative in databases

from bioaerosol samples belonged to a single phylotype related to Bacillus pumilus with a high similarity of 99.6\%. These sequences formed an identical cluster with another phylotype (DDd-31 and DDd-33) from the DNA directly extracted from bioaerosol samples. One phylotype consisting of bands DAd-1, DAd-3, DAd-7, DAd-12, DAd-16, and DAd-18 was also related to B. pumilus with a high similarity of $99.4 \%$. Three other phylotypes, bands DAd-9, DAd-10, and DAd-20, respectively, obtained from microbial cultures below $10 \% \mathrm{NaCl}$, were related to $B$. pumilus with similarities below $98.1 \%$ and formed a cluster between the clusters of Bacillus and Staphylococcus on the phylogenetic tree. The three sequences of DAd13, DAd-27, and DAd-29 were specific to the microbial cultures of 10 and/or $20 \% \mathrm{NaCl}$ and were classified into two phylotypes belonging to the genus Staphylococcus. Phylotype DAd-27/ DAd-29 detected from the microbial cultures of a bioaerosol sample collected at $10 \mathrm{~m}$ was identical to Staphylococcus xylosus and another phylotype (DAd-13), obtained from the microbial cultures of a bioaerosol sample collected at $800 \mathrm{~m}$, was related to $S$. epidermidis with a high similarity of $99.8 \%$, indicating the difference between the bacterial species with altitude.

\section{Discussion}

The results from several field investigations (Griffin 2007; Kellogg and Griffin 2006) indicate that microorganisms in the atmosphere are transported around the world and influence ecological systems. In our study, the epifluorescence microscopy analysis detected bacterial cells attached to the surfaces of mineral particles collected at an altitude of $800 \mathrm{~m}$ (Fig. 2). As this observation demonstrated microbial transport by atmospheric dispersion, we subsequently investigated bacterial species composition and aspects associated with viability. The vertical distribution of microorganisms was also interest in this KOSA source region (Dunhuang City, China) as bacterial populations vertically carried from the ground area may be transported to other regions, thereby expanding their habitats to other environments. 


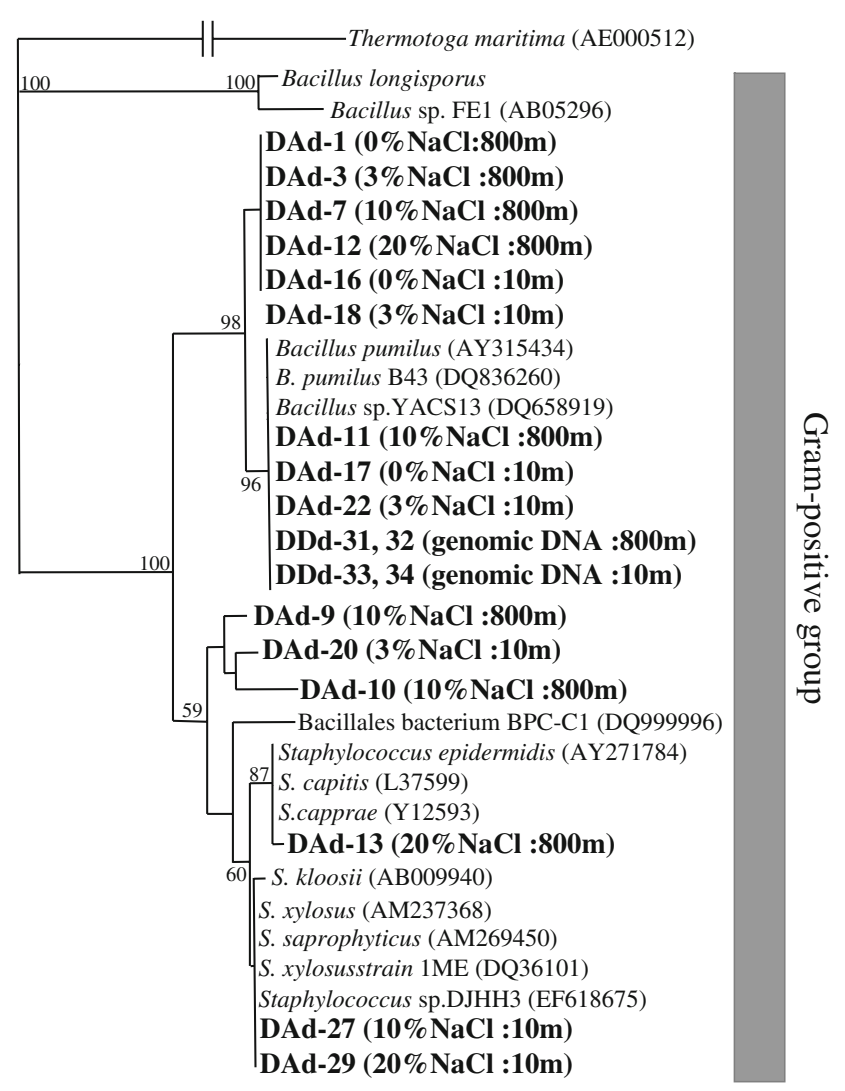

0.1

Fig. 6 Phylogenetic tree including the partial sequences of 16S rDNA amplicons excised from the DGGE gel shown in Fig. 5. The tree was calculated from a dissimilarity matrix of approximately $450 \mathrm{bp}$ (Escherichia coli numbering 422-886) alignment using a neighborjoining algorithm. The accession number of each reference sequence is also given. Sample information $(\mathrm{NaCl}$ concentrations in the culture medium or genomic DNA directly extracted from bioaerosol sample) is shown in parentheses. Bootstrap values larger than 50\% (after 1000 resampling) are indicated on the branches

Microbial growth in bioaerosol samples collected at heights of 10 and $800 \mathrm{~m}$ above the ground was observed in media containing $\mathrm{NaCl}$ at concentrations ranging from 0 to $20 \%$ (Fig. 4). The microbial cultures growing in media with an $\mathrm{NaCl}$ amendment and the DNA directly extracted from the bioaerosol samples were examined using by PCRDGGE, and eight phylotypes belonging to the genus Bacillus and the genus Staphylococcus (Gram-positive bacteria) were identified (Table 1, Fig. 6). These data indicate that the atmospheric bacterial community over Dunhuang City has a low diversity and is dominated by a few Gram-positive bacterial species of the genus Bacillus and Staphylococcus. In a previous investigation at Dunhuang City in August 2006, Gram-positive bacterial species of the genus Bacillus were isolated from bioaerosol samples collected at a height of $100 \mathrm{~m}$ (Kobayashi et al. 2007). Bacillus sp. is known to form endospores, which are resistant to environment stress and therefore enhance their survival in the atmosphere (Riesenman and Nicholson 2000). The desiccation condition in atmosphere would select the spore-forming bacterial survival and reduce the diversity of microbial community.

Halobacteria, including Gram-positive bacteria, are capable of survival in extreme environments through their resistance to several types of stress, such as desiccation, UV irradiance, extreme temperature, oxygen limitation, and high salinity (Rothschild and Mancinelli 2001; Russell 1989). Echigo et al. reported that similar members of halobacteria inhabit non-saline environments in an area surrounding Tokyo, Japan, and indicated that they may have been introduced by KOSA events (Echigo et al. 2005). Some halobacterial species that were found in both the Gobi Desert and the atmospheric dust impacting Japan had similar genetic identities, thereby supporting the hypothesis of KOSA transport and deposition (Hua et al. 2007). The results of this investigation suggest that, at high attitudes, the extreme halophilic bacteria would maintain their viabilities and be tolerant to the strict environmental stresses of atmosphere.

Our phylogenetic analysis using partial 16S rDNA sequences revealed that the composition of the bacterial species was similar in the bioaerosol samples collected at 10 and $800 \mathrm{~m}$ (Fig. 6). In particular, the sequences obtained from the DNA directly extracted from bioaerosol samples were identical in bioaerosol samples collected at both altitudes, and the two phylotypes of these sequences were closely related to a single bacterial species, $B$. pumilus. The size distribution of aerosol particles at the heights of 10 and $800 \mathrm{~m}$ was also similar, suggesting that the aerosol particles of desert-sand origin were vertically well mixed (Fig. 2). In a previous investigation, terrestrial bacteria belonging to the genus Bacillus were isolated at $20,000 \mathrm{~m}$ above the ground, supporting the concept of vertical transportion of microorganisms into the Earth's upper atmosphere (Griffin 2004). Therefore, as a result of active mixing processes in China's KOSA source region, viable halobacterial cells associated with mineral particles may be transported over vast distances

The phylotypes in cultures grown on media containing 0,3 , and $10 \% \mathrm{NaCl}$ belonged to the genus Bacillus and were close relatives of, or identical to, B. pumilus (Fig. 6). Species of Bacillus are tolerant of wide rages of $\mathrm{NaCl}$ concentrations. Moreover, phylotypes identified as B. pumilus were also obtained from the DNA directly extracted from bioaerosol samples, suggesting that these phylotypes would dominate in a KOSA-laden atmosphere. One strain of B. pumilus has been identified as a toxin-producing human pathogen (Hoult and Tuxford 1991) and has been isolated from an aerosol in the northern Caribbean during African dust events (Griffin et al. 2003). This species has been isolated in both open ocean and coastal marine environments (Banerjee et al. 2007; Ivanova et al. 1999). 
The two phylotypes with DAd-13, DAd-27, and DAd-29, which were specific to bioaerosols cultured on media containing $10 \mathrm{and} /$ or $20 \% \mathrm{NaCl}$, were closely related to species of the genus Staphylococcus. These isolates are considered to be the halophilic bacteria and therefore require some concentration of $\mathrm{NaCl}$ for growth. These phylotypes were not detected from the DNA directly extracted from bioaerosol samples, indicating that Staphylococcus is a less dominant member of the bacterial community in the atmosphere over Dunhuang City and/or in the KOSA source regions. Several members of the genus Staphylococcus, which often colonize on the skin or in the oral cavities of humans, are capable of causing human disease (Spellerberg et al. 1998; Zhang et al. 2003) and are known to survive aerosol transport (Wisplinghoff et al. 2003). Related bacterial species, such as $S$. xylosus and $S$. epidermidis, in addition to B. pumilus, have been identified in aerosols collected from the northern Caribbean during African dust events (Griffin et al. 2003). The findings of this study indicate that Staphylococcus sp. can maintain viability during atmospheric dust transport and easily distribute to habitats.

In this study, we found that a halobacterial community composed of members of the genus Bacillus and Staphylococcus was present in the atmosphere over Dunhuang City. Based on our results, we believe that active mixing processes of the boundary layer transport viable cells associated with mineral particles from the desert surface to an altitude of $800 \mathrm{~m}$. In particular, we found that B. pumilus predominated throughout the boundary layers of the atmosphere. These communities may serve as seeds in downwind ecosystems over vast distances. The $\mathrm{NaCl}$ amendment halobacteria technique employed in this study has a potential for use in bacterial transport research geared towards understanding the influence of ecological change through time and the possible effects on human and animal health in downwind environments.

Acknowledgements This research was supported by a Grant-in-Aid for the Encouragement of Young Scientists (20710024) from the Ministry of Education, Science, Sports, and Culture, Japan. The Salt Science Research Foundation, No. 0823, also supported this work. This research was supported by the Global Environment Research Fund (RF-072) provided by the Ministry of the Environment, Japan.

Open Access This article is distributed under the terms of the Creative Commons Attribution Noncommercial License which permits any noncommercial use, distribution, and reproduction in any medium, provided the original author(s) and source are credited.

\section{References}

Alan MJ, Harrison RM (2004) The effects of meteorological factors on atmospheric bioaerosol concentrations - a review. Sci Total Environ 326:151-180. doi:10.1016/j.scitotenv.2003.11.021
Banerjee S, Devaraja TN, Shariff M, Yusoff FM (2007) Comparison of four antibiotics with indigenous marine Bacillus spp. in controlling pathogenic bacteria from shrimp and Artemia. J Fish Dis 30:383-389. doi:10.1111/j.1365-2761.2007.00819.x

Duce RA, Unni CK, Ray BJ, Prospero JM, Merrill JT (1980) Longrange atmospheric transport of soil dust from Asia to the tropical North Pacific: temporal variability. Science 209:1522-1524. doi:10.1126/science.209.4464.1522

Echigo A, Hino M, Fukushima T, Mizuki T, Kamekura M, Usami R (2005) Endospores of halophilic bacteria of the family Bacillaceae isolated from non-saline Japanese soil may be transported by Kosa event (Asian dust storm). Saline Systems 2005:1-8

Fabian MP, Miller SL, Reponen T, Hernandez MT (2005) Ambient bioaerosol indices for indoor air quality assessments of flood reclamation. J Aerosol Sci 36:763-783. doi:10.1016/j.jaerosci. 2004.11.018

Griffin DW (2004) Terrestrial microorganisms at an altitude of 20,000 $\mathrm{m}$ in Earth's atmosphere. Aerobiologia 20:135-140. doi:10.1023/ B:AERO.0000032948.84077.12

Griffin DW (2007) Atmospheric movement of microorganisms in clouds of desert dust and implications for human health. Clin Microbiol Rev 20:459-477. doi:10.1128/CMR.00039-06

Griffin DW, Kellogg CA (2004) Dust storm and their impact on ocean and human health: dust in Earth's atmosphere. EcoHealth 1:284 295. doi:10.1007/s10393-004-0120-8

Griffin DW, Kellogg CA, Garrison VH, Lisle JT, Borden TC, Shinn EA (2003) Atmospheric microbiology in the northern Caribbean during African dust. Aerobiologia 19:143-157. doi:10.1023/B: AERO.0000006530.32845.8d

Griffin DW, Douglas AE, Westphal AE, Gray MA (2006) Airborne microorganisms in the African desert dust corridor over the midAtlantic ridge, Ocean Drilling Program, Leg 209. Aerobiologia 22:211-226. doi:10.1007/s10453-006-9033-Z

Grinshpun SA, Clark JM (2005) Measurement and characterization of bioaerosols. J Aerosol Sci 36:553-555. doi:10.1016/j.jaerosci. 2005.03.001

Hoult B, Tuxford AF (1991) Toxin production by Bacillus pumilus. J Clin Pathol 44:455-458. doi:10.1136/jcp.44.6.455

Hua NP, Kobayashi F, Iwasaka Y, Shiand GY, Naganuma T (2007) Detailed identification of desert-originated bacteria carried by Asian dust storms to Japan. Aerobiologia 23:291-298. doi:10.1007/s10453-007-9076-9

Imshenetsky AA, Lysenko SV, Kazakov GA (1978) Upper boundary of the biosphere. Appl Environ Microbiol 35:1-5

Ivanova EP, Vysotskii MV, Svetashev VI, Nedashkovskaya OI, Gorshkova NM, Mikhailov VV et al (1999) Characterization of Bacillus strains of marine origin. Int Microbiol 2:267-271

Iwasaka Y, Minoura H, Nagaya K (1983) The transport and spacial scale of Asian dust-storm clouds: a case study of the dust-storm event of April 1979. Tellus 35B:189-196

Iwasaka Y, Yamato M, Imasu R, Ono A (1988) The transport of Asia dust (KOSA) particles; importance of weak KOSA events on the geochemical cycle of soil particles. Tellus 40B:494-503

Jones AM, Harrison RM (2004) The effects of meteorological factors on atmospheric bioaerosol concentrations - a review. Sci Total Environ 326:151-180. doi:10.1016/j.scitotenv.2003.11.021

Kalogerakis N, Paschali D, Lekaditis V, Pantidou A, Eleftheriadis K, Lazaridis M (2005) Indoor air quality - bioaerosol measurements in domestic and office premises. J Aerosol Sci 36:751-761. doi:10.1016/j.jaerosci.2005.02.004

Kellogg CA, Griffin DW (2006) Aerobiology and the global transport of desert dust. Trends Ecol Evol 21:638-644. doi:10.1016/j. tree.2006.07.004

Kellogg CA, Griffin DW, Garrison VH, Peak KK, Royal N, Smith RR et al (2004) Characterization of aerosolized bacteria and fungi 
from desert dust events in Mali, West Africa. Aerobiologia 20:99-110. doi:10.1023/B:AERO.0000032947.88335.bb

Kobayashi F, Kakikawa M, Yamanda M, Chen B, Shi GY, Iwasaka Y (2007) Study on atmospheric diffusion of bioaerosols in a KOSA source region. Earozoru Kenkyu 22:218-227

Lorenz N, Hintemann T, Kramarewa T, Katayama A, Yasuta T, Marschner P et al (2006) Response of microbial activity and microbial community composition in soils to long-term arsenic and cadmium exposure. Soil Biol Biochem 38:1430-1437. doi:10.1016/j.soilbio.2005.10.020

Maki T, Hasegawa H, Watarai H, Ueda K (2004) Classification for dimethylarsenate-decomposing bacteria using restrict fragment length polymorphism analysis of $16 \mathrm{~S}$ rRNA genes. Anal Sci 20:61-68. doi:10.2116/analsci.20.61

Mancinelli RL, Shulls WA (1987) Airborne bacteria in an urban environment. Appl Environ Microbiol 35:1095-1101

Muyzer G, de Waal EC, Uitterlinden AG (1993) Profiling of complex microbial populations by denaturing gradient gel electrophoresis analysis of polymerase chain reaction-amplified genes coding for 16S rRNA. Appl Environ Microbiol 59:695-700

Okamoto T, Maruyama A, Imura S, Takeyama H, Naganuma T (2004) Comparative phylogenetic analyses of Halomonas variabilis and related organisms based on $16 \mathrm{~S}$ rRNA, gyrB and ectBC gene sequences. Syst Appl Microbiol 27:323-333. doi:10.1078/07232020-00271

Olsen RA, Bakken LB (1987) Viability of soil bacteria; optimization of plate-counting technique and comparison between total counts and plate counts within different size groups. Microb Ecol 13:5974. doi:10.1007/BF02014963

Porter KG, Feig YS (1980) The use of DAPI for identifying and counting aquatic microflora. Limnol Oceanogr 25:943-948

Prospero JM, Blades E, Mathison G, Naidu R (2005) Interhemispheric transport of viable fungi and bacteria from Africa to the Caribbean with soil dust. Aerobiologia 21:1-19. doi:10.1007/ s10453-004-5872-7

Riesenman PJ, Nicholson L (2000) Role of the spore coat layers in Bacillus subtilis spore resistance to hydrogen peroxide, artificial UV-C, UV-B, and solar UV radiation. Appl Environ Microbiol 66:620-626. doi:10.1128/AEM.66.2.620-626.2000
Rothschild LJ, Mancinelli RL (2001) Life in extreme environments. Nature 409:1092-1100. doi:10.1038/35059215

Russell NJ (1989) Adaptive modifications in membranes of halotolerant and halophilic microorganisms. J Bioenerg Biomembr. 21:93-113. doi:10.1007/BF00762214

Russell WC, Newman C, Williamson DH (1974) A simple cytochemical technique for demonstration of DNA in cells infected with mycoplasms and viruses. Nature 253:461-462. doi:10.1038/253461a0

Saitou N, Nei M (1987) The neighbor-joining method: A new method for reconstructing phylogenetic trees. Mol Biol Evol 4:406-425

Spellerberg B, Steidel K, Lütticken R, Haase G (1998) Isolation of Staphylococcus caprae from blood cultures of a neonate with congenital heart disease. Eur J Clin Microbiol Infect Dis 17:6162. doi:10.1007/BF01584369

Suehiro F, Kobayashi T, Nonaka L, Tuyen BC, Suzuki S (2006) Degradation of tributyltin in microcosm using mekong river sediment. Microb Ecol 52:19-25. doi:10.1007/s00248-006-9079-Z

Wisplinghoff H, Rosato AE, Enright MC, Noto M, Craig W, Archer GL (2003) Related clones containing SCCmec type IV predominate among clinically significant Staphylococcus epidermidis isolates. Antimicrob Agents Chemother 47:3574-3579. doi:10.1128/AAC.47.11.3574-3579.2003

Wu PC, Tsai JC, Li FC, Lung SC, Su HJ (2004) Increased levels of ambient fungal spores in Taiwan are associated with dust events from China. Atmos Environ 38:4879-4886. doi:10.1016/j.atmosenv. 2004.05.039

Yamada M, Iwasaka Y, Matsuki A, Trochkine D, Kim YS, Zhang D et al (2005) Feature of dust particles in the spring free troposphere over Dunhuang in Northwestern China: Electron microscopic experiments on individual particles collected with ballon-borne impactor. Water Air Soil Pollut 5:231-250. doi:10.1007/s11267005-0741-0

Yeo HG, Kim JH (2002) SPM and fungal spores in the ambient air of west Korea during the Asian dust (Yellow sand) period. Atmos Environ 36:5437-5442. doi:10.1016/S1352-2310(02)00672-6

Zhang YQ, Ren SX, Li HL, Wang YX, Fu G, Yang J et al (2003) Genome-based analysis of virulence genes in a non-biofilm-forming Staphylococcus epidermidis strain (ATCC 12228). Mol Microbiol 49:1577-1593. doi:10.1046/j.1365-2958.2003.03671.x 